\title{
The Independence of the Business Competition Court from the Perspective of Law Enforcement System in Indonesia
}

\author{
Dr. Rihantoro Bayuaji, S.H., M.H $\quad$ Budi Endarto, S.H., M.Hum \\ Lecturer in Faculty of Law, Wijaya Putra University, Benowo Road No. 1-3, Surabaya, PO. BOX. 60195, East \\ Java, Indonesia
}

\begin{abstract}
Fair competition law enforcement on business competition issues in Indonesia is very important to ensure the situation of conducive business competition and the enforcement in Law Number 5 of 1999 on the Prohibition of Monopolistic Practices and Unfair Business Competition, therefore the Commission for the Supervision of Business Competition of the Republic of Indonesia (KPPU) is actively involved in issuing related regulations with law enforcement procedures on business competition cases in Indonesia, which is through KPPU Regulation Number 1 of 2010 on Procedures for Case Handling. The judicial system of the business competition court in Indonesia can not be separated from the role of the KPPU as an institution that has the function of regulating and supervising competition behaviour, whether using prohibited activity patterns or agreements. In the context of law enforcement on business competition cases, KPPU has the authority from performing investigations to examining and deciding the competition cases in judicial institutions held by KPPU. Observing the main function of KPPU as a supervisory institution and situation regulator of the business competition in Indonesia, the authority of KPPU that perform investigations to judge business competition cases certainly is not an issue that needs to be debated. However, from the perspective of the justice system in Indonesia, KPPU's authority in conducting investigations, examining, and deciding cases is a matter that needs to be studied more deeply, specifically regarding the guarantee of justice sense for business actors who are positioned as Reported Party.
\end{abstract}

Keywords: Independence, Business Competition Court, Law Enforcement

DOI: $10.7176 / \mathrm{JLPG} / 102-07$

Publication date:October $31^{\text {st }} 2020$

\section{Background}

Generally, people are performing business activities to gain profit and income to meet their daily needs. Based on fulfilling life necessities, they run many businesses, both similar and different business activities. This situation will raise and create business competition among the business actors. Therefore, competition in a business is a natural thing. Then it can be said that business competition factor is an absolute requirement. (conditio sine qua non), to create market economy, which is the balance between demand and supply, although sometimes either fair or unfair competition arises. Fair business competition certainly has a positive impact on both fellow business and consumers. For business actors, fair business competition is a factor that raises motivation or stimulation to increase efficiency, productivity, innovation, and the quality of the products they produce. This surely has an impact on consumers, because they will get benefit from the fair business competition, for instance, consumers will get many choices and competitive price of the demanding product or service.

A competitive business atmosphere is an absolute requirement for developing countries, such as Indonesia, to achieve efficient economic growth, including the industrialization process. In a competitive market, companies will compete with each other to attract more consumers by selling their products at the lowest possible price. They also will compete to improve the product quality and services to consumers. To succeed in a competitive market, companies must strive in developing new production processes that are more efficient, as well as developing new products with new innovative designs. By this reason, companies need to develop and improve their technological capabilities, both process technology and product technology. This way hopefully will encourage the technological process and economic growth. ${ }^{1}$ Regulation regarding the prohibition of monopoly and unfair business competition is necessary to ensure that the freedom to compete economically can perform without any obstacle because the essence of business actors in running the business is always competitive. Competition can be performed both positively and negatively. The negative (unfair) business competition will result in:

a. The death or reduced of the competition among business actors;

b. The arise of monopolistic practices, in which the market is only controlled by one business actor;

c. The tendency of business actors to exploit consumers by selling expensive goods without adequate quality. ${ }^{1}$

To ensure an atmosphere of fair business competition as mandated by Law Number 5 of 1999 on the Prohibition of Monopolistic Practices and Unfair Business Competition, it certainly must be followed by the establishment of a fair law enforcement system. Law Number 5 of 1999 on the Prohibition of Monopolistic

\footnotetext{
${ }^{1}$ Hikmahanto Juwana, An Overview of Competition Law and Law Number. 5 of 1999, Journal of Law Master I of 1999 , pg. 32
} 
Practices and Unfair Business Competition does not only regulate material law but also its procedural law (formal law). However, if it is examined further, it turns out that the procedure of the business competition law in Law Number 5 of 1999 on the Prohibition of Monopolistic Practices and Unfair Business Competition is not regulating in detail and clearly, for instance, procedural law in trials, legal effort. By this reason, the formal law of business competition is complemented by the Regulation of the Business Competition Supervisory Commission (KPPU) and the Regulation of the Supreme Court of the Republic of Indonesia.

\section{The Authority of the Business Competition Supervisory Commission of the Republic of Indonesia} (KPPU)

KPPU is an institution which is formed in line with the issuance of Law Number 5 of 1999 on the Prohibition of Monopolistic Practices and Unfair Business Competition. Article 1 Number (18) of Law Number 5 of 1999 on the Prohibition of Monopolistic Practices and Unfair Business Competition stated :

"The Business Competition Supervisory Commission is a commission that is established to supervise business actors in performing their business activities to not engage in monopolistic practices and/or unfair business competition."

Furthermore, in Article 1 paragraph (2) of Presidential Decree Number 75 of 1999 as amended to Presidential Regulation Number 80 of 2008 as stated below:

"The commission as referred in paragraph (1) is a non-structural institution which is independent of the influence and power of the government and other parties."

The tasks and authorities of KPPU in detail is regulated in Article 35 of Law Number 5 of 1999 on the Prohibition of Monopolistic Practices and Unfair Business Competition, which includes:

1. Assessing agreements which lead possibility to monopolistic practices and/or unfair business competition as regulated in Article 4 to 16;

2. Evaluating business activities and/or business actors which lead possibility to monopolistic practices and/or unfair business competition as regulated in Article 17 to 24;

3. Conducting an assessment of manipulation of a dominant position which leads possibility to monopolistic practices and/or unfair business competition as regulated in Article 25 to 28;

4. Taking actions in accordance with the KPPU's authority as regulated in Article 36;

5. Providing advice and considerations of the government policies related to the monopolistic practices and/or unfair business competition;

6. Developing guidelines and/or publications related to Antimonopoly Law;

7. Providing regular reports based on the results of KPPU's work to the President and DPR.

\section{Independence Concept of the Business Competition Court in Indonesia}

According to the KPPU's legal structure, in Article 1 paragraph (2) of Presidential Decree Number 75 of 1999 as amended to Presidential Regulation Number 80 of 2008 as stated below:

"The commission as referred in paragraph (1) is a non-structural institution which is independent from the influence and power of the government and other parties."

This norm is a form of independence concept of the KPPU's legal structure. However, Business Competition Court in is not only viewing the KPPU's legal structure but also must refer to the KPPU's authority holistically. The independence of the judiciary is very important as it is used as a study because this case involves law enforcement. Generally, KPPU has extraordinary powers as executive, judicative, legislative, and consultative. ${ }^{2}$ The extraordinary of KPPU is clearly visible in its authority as regulated in Article 36 of Law Number 5 of 1999 on the Prohibition of Monopolistic Practices and Unfair Business Competition as stated below:

1. Receiving reports from the public and/or business actors regarding the alleged occurrence of monopolistic practices and/or unfair business competition;

2. Researching allegations of business activities and/or business actors which may result to monopolistic practices and/or unfair business competition;

3. Conducting investigations and/or examinations on allegations of monopolistic practices and/or unfair business competition that is reported by public or business actors, or presenting business actors, witnesses, expert of witnesses, or any person as referred in letter (e) or letter (f), that is not willing to fulfil the commission summons;

4. Requesting information from government agencies regarding to the investigations and/or examinations of business actor who violate the provisions of this law;

5. Obtaining, examining, and/or assessing letters, documents, or other evidence for investigation and/or examination;

6. Deciding and determining any harm of the other business actors or public;

7. Informing the Commission's decision to the business actor who is suspected in engaging in monopolistic practices and/or unfair business competition; 
8. Imposing sanctions in the form of administrative action to business actors who violates the provision of the law.

Referring to the KPPU's authorities, it is clear that KPPU has extraordinary powers, from investigating to deciding the violation of the provision of the business competition law by imposing sanctions.

\section{The Characteristics of Business Competition Procedural of Law in Indonesia}

The characteristics of the Business Competition Procedural Law in Indonesia was initially born from the KPPU Regulations that arranged the procedures for handling cases. Typically, procedural law (formal law) in the material legal domain is regulated in-laws, for instance Formal Law of criminal is regulated in Law Number 8 of 1981 on Criminal Procedural Law, Formal Law of civil is regulated in HIR, Formal Law of the administrative realm is regulated in Laws Number 5 of 1986 on State Administrative Court, and Law Number 9 of 2004 on the Alteration of Laws Number 5 of 1986 on State Administrative Court.

However, those laws are different from business competition law. In-Laws Number 5 of 1999 on the Prohibition of Monopolistic Practices and Unfair Business Competition, it is regulated that Formal Law of business competition only has 8 (eight) articles, which begins from Article 38 to 46 Chapter VII on Case Handling Procedures. Apart from that, the Formal Law of business competition in Indonesia is regulated in KPPU Regulations. In 2010, KPPU issued the Regulations of KPPU Number 1 of 2010 on Case Handling Procedures. This regulation is from Chapter VII on Case Handling Procedures as regulated in Law Number 5 of 1999 on the Prohibition of Monopolistic Practices and Unfair Business Competition. It is concluded that the Formal Law in Indonesia is still experiencing a vacuum at the level of norms in-laws.

\section{Position of KPPU in Law Perspective of Business Competition Procedural}

KPPU's legal structure in the perspective of Business Competition Procedural Law is seen in its authority in Law Number 5 of 1999 on the Prohibition of Monopolistic Practices and Unfair Business Competition and KPPU Regulations. The newest regulation is KPPU Regulations Number 1 of 2019 of Case Handling of Monopolistic Practices and Unfair Business Competition. Based on that regulation, particularly Chapter IV on Commission Assembly Trial, it is regulated regarding to the trial procedures which is held by Commission Council. The Commission Assembly is regulated in Article 1 Number 18 of KPPU Regulations Number 1 of 2019, as defined:

"Assembly consisting of at least 3 (three) commission members who are tasked to examine and decide cases."

Referring to Article 1 Number 18 of KPPU Regulations Number 1 of 2019, trials in business competition cases are examined and decided by the commissioner in the KPPU institution. Furthermore, in business competition procedural law, there is "Examination Investigator" and "Prosecution Investigator". Both concepts is regulated in Article 2 Number (23) and (24) of KPPU Regulations Number 1 of 2019, as stated:

Article 1 Number (23)

"Examination Investigator is commission staff who is assigned to perform clarification, researches, and investigation activities."

Article 1 Number (24)

"Prosecution Investigator is commission staff who is assigned to perform filling activities or reading the Report of Alleged Violation at the Preliminary Examination, submitting evidence, presenting witnesses, and conveying conclusions at the follow-up examination. "

The positions of examination investigator and prosecution investigator are also part of KPPU's internal. Therefore, the positions of examination investigator, prosecution investigator, and Commission Council can be briefly described as follow:
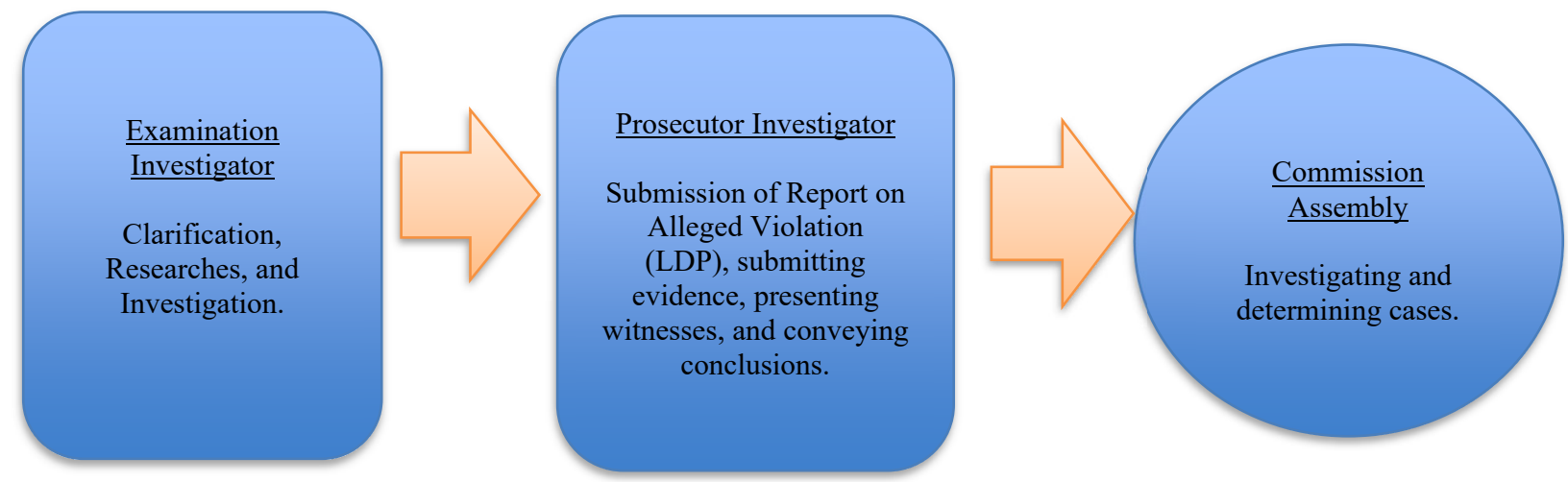

Based on that flow chart, it can be concluded that the position of KPPU in business competition procedural law context is not independent as another dispute court. From the clarification, researches, investigation, prosecution, to decision making by trials, are all performed by organs within the KPPU institution. Therefore, this 
order is correlated with the theory of independence, which includes neutral characteristics. It is seen that the KPPU institution in the business competition procedural law is not independent.

\section{Conclusion}

The authority of KPPU from the clarification, researches, investigation, prosecution, to decision making, are all performed by organs within the KPPU institution. Therefore, this order is correlated with the theory of independence, which includes neutral characteristics. It is seen that the KPPU institution in the business competition procedural law is not independent.

\section{References}

Adi Nugroho, Susanti, Competition Business Law in Indonesia, Sinar Grafika, Jakarta, 2013

Adi Nugroho, Susanti, Competition Business Law in Indonesia, $2^{\text {nd }}$ Publication, Kencana Prenada Media Group, Jakarta, 2014;

Ali, Achmad, Reveal the Legal Theory and Juridical Prudenc), $5^{\text {th }}$ Publication, Kencana Prenada Media Group, Jakarta, 2013;

Thee Kian Wie, Economic Aspects that Need to be Considered in the Implementation of Law Number 5 of 1999 ;

Usman, Rachmadi, Business Competition Procedural Law in Indonesia, Sinar Grafika, 1 st Publication, Jakarta; 